\title{
“Is Christus verdeeld?” Nadenke oor die teologiese regverdiging van kerkverdeeldheid en kerkskeuring ${ }^{1}$
}

J H van Wyk

(Noordwes-Universiteit, Potchefstroom)

\section{ABSTRACT \\ "Is Christ divided?" Reflections on the theological justification of church disunity and church schism}

In this article the author investigates the question whether a church schism could ever be justified. He considers on the one hand the Biblical message on church unity and on the other hand the many justifications of church disunity (schism). He concludes that most of these justifications are unacceptable rasionalisations and that PostReformation theology distanced itself far away from Biblical ecclesiology in this regard.

\section{INLEIDING}

“Is Christus verdeel?”, dít is die kritiese vraag wat die apostel Paulus aan die ekklesia van Korinte stel waar schismata ontstaan en groepvorming ontwikkel het rondom Paulus, Apollos, Sefas en Christus. "Is Paulus miskien vir julle gekruisig, of is julle in die naam van Paulus gedoop?”, is die Apostel se ontstelde vraag. Asof hy wou sê: hoe op aarde is dit moontlik! 'n Verdeelde ekklesia veronderstel ' $n$ verdeelde Christus, en ' $n$ verdeelde Christus is ' $n$ dooie Christus. 'n Verdeelde ekklesia (gemeente/kerk) moet daarom 'n dooie gemeente/kerk wees.

Uiteraard moet ons daarmee rekening hou dat Paulus se eerste brief aan die Korintiërs gerig was aan 'n lokale gemeente/kerk en dat hy hier dus vir eenheid in die lokale gemeente gepleit het ${ }^{2}$. Die moderne

1 Hierdie artikel is bedoel as waarderings- en dankwoord aan kollega Conrad Wethmar vir sy bydrae tot die uitbou van die reformatoriese teologie in Suid-Afrika. Die artikel is in gewysigde vorm ook gebruik as voordrag tydens 'n konferensie van die International Reformed Theological Institute (IRTI) in Cluj-Napoca, Romenië, 3-8 Julie 2007.

2 Die Nuwe-Testamentiese konsep ekklesia kan teruggevoer word na die Ou-Testamentiese kahal Jahweh, die volk van God, en verwys na die versamelde gemeente/gelowiges; dit is vertaal met die Romaanse woord 'kongregasie' ('gemeente'). Die Germaanse woord 'kerk' ('church') hou verband met die Griekse kuriakos wat verwys na 'hulle wat aan die Here 
probleem van onenigheid en verskeurdheid waar bepaalde gemeentes hulle van ander gemeentes afgroepeer en sodoende 'denominasies' vorm, het Paulus nie geken nie en sou vir hom waarskynlik net so onaanvaarbaar gewees het as onenigheid in 'n plaaslike gemeente'.

Sedert my beginjare as teologiese student het ek die werklikheid van 'n verskeurde kerklike situasie as 'n pynlike probleem ervaar en het ek algaande tot die konklusie gekom dat die gereformeerde teologie hom in geen ander aspek só ver van die beginsel van die sola Scriptura verwyder het as in die ekklesiologie nie, en spesifiek dan ten opsigte van die vraagstelling oor die eenheid van die kerk van Christus.

Dit bring ons onmiddellik by die vraag: kán die kerk van Christus verdeel - en nog kérk bly?

\section{KAN CHRISTUS VERDEEL WORD?}

Dit is belangrik om in hierdie verband nie te vergeet wat die $\mathrm{Ou}$ Testament oor kerkeenheid leer nie (Schuman 1981:16-59; Berkhof sj:22-

behoort' (kyk Wentsel 1998:21-22; Küng 1967:95-102; Schmidt 1985:394402). Ekklesia verwys altyd na die lokale gemeente/kerk (Matt 18:17, Rom, 1 Kor) of die 'universele kerk/gemeente' (Matt 16:18; Ef; Kol). ' $n$ 'Kerk' bestaan nie uit 'gemeentes' nie maar uit gelowiges (Snyman 1977:24-25, 35-50, 76-87). Dit is daarom verwarrend om te praat van 'n 'kerk' wat uit 'gemeentes' bestaan - net so verwarrend as wat dit sou wees om te praat van 'n 'gemeente' wat uit 'kerke' bestaan. Barth (1960:750) merk tereg op dat die Nuwe-Testamentiese ekklesiai nie na verskillende 'kerke' verwys nie (soos ons dit vandag ken), maar na lokale gemeentes wat geografies geskei is. Die enigste moontlike uitsondering is Hand 9:31, maar dit moet in gedagte gehou word dat die ekklesia van Jerusalem destyds die enigste ekklesia was. In Rom en 1 Kor verwys die 'liggaam van Christus' na die plaaslike gemeente, in Ef en Kol na die universele kerk (Küng 1967:265). Ter wille van diskussie word later die term 'denominasie' gebruik (vir ' $n$ aantal gemeentes wat saamgroepeer as ' $n$ aparte kerkgemeenskap). Dis egter terminologie wat nie in die Skrif steun vind nie.

3 Die volgende (onvolledige) data van 1998 illustreer die situasie van kerklike verdeeldheid (Wentsel 1998:311): Nestoriane, 25 miljoen; Kopties, 8 miljoen; Oosters-Ortodoks, 224 miljoen; Rooms-Katoliek, 1000 miljoen; Luthers, 65 miljoen; Gereformeerd, 50 miljoen; Anglikaans, 60 miljoen; Baptiste, 35 miljoen; Metodiste, 50 miljoen; Pentekostaliste, 461 miljoen. Die REC News Exchange van February 2000 berig dat "there are 33,800 denominations around the world, and people form a new one nearly every day" (37/2:3). Vgl Wentsel (2006:373-374). 
27), maar vir die doeleindes van hierdie artikel word veral op die gegewens van die Nuwe Testament oor eenheid, verskeidenheid en onenigheid/verskeurdheid gekonsentreer.

In die ganse verkondiging van die Nuwe Testament is daar nêrens gegewens oor of ' $n$ oproep tot verskeurdheid of verdeeldheid tussen die verskillende ekklesiai nie. Die klem val voortdurend op eenheid, eenheid in die plaaslike gemeente en eenheid tussen die plaaslike gemeentes. In die vroeë fase was daar verskeie ekklesiai in verskillende lande, elk met sy eie karakter en eie probleme: in KleinAsië/Turkye (Kolosse, Derbe, Efese, Galasië, Laodisea, Listra, Pergamum, Filadelfia, Sardis, Smirna, Tiatira); in die Midde-Ooste (Jerusalem, Judea, Galilea, Samaria, Antiogië); in Griekeland (Korinte, Filippi, Berea, Tessalonika); en in Italië (Rome). Dit is begryplik dat die Joods-Christelike gemeente in Jerusalem 'n meer formele liturgie sou gevolg het as die ekstatiese Christene in Korinte. Maar wat almal saamgebind het, was die geloof in die een ware God, in Jesus as Messias en Here, in die krag van die Heilige Gees.

Nêrens is daar enige teken, enige suggestie of enige opdrag dat sommige van hierdie ekklesiai, of 'n groep Christene in 'n lokale ekklesia, hulle moet afgroepeer en dan 'n aparte ekklesia of 'denominasie' moet vorm wat mekaar van die doop en nagmaal uitsluit nie. Nêrens nie!

Wat in die Nuwe Testament deurgaans beklemtoon word, is die eenheid van die onderskeie ekklesiai.

Die verkondiging van Jesus is duidelik in hierdie verband. Vir die goeie herder kan daar slegs "een herder met een kudde" wees (Joh 10:16) - bestaande uit Joodse en heiden-Christene. Kort voordat Hy gevange geneem is, bid Hy dat al sy navolgers "almal (volkome) een mag wees", só een soos die Vader in Hom en Hy in die Vader is, "sodat die wêreld kan glo dat die Vader Hom gestuur het" (Joh 17:21) (sien Durand 1986:105-133; Wentsel 1998:249, 254). Die geloofwaardigheid van die kerk is hier op die spel: ' $n$ onenige, verdeelde en verskeurde kerk is ' $n$ struikelblok vir die wêreld om te glo. Dit maak die boodskap van liefde, versoening en vrede wat die kerk verkondig (en moet uitleef), ongeloofwaardig en onaanvaarbaar.

Dieselfde boodskap resoneer in die briewe. Paulus vermaan die Christene in Rome om "eensgesind onder mekaar te wees" (Rom 12:16;15:5). Op die Korintiese Christene doen Paulus 'n beroep om almal "eensgesind te wees”. En hy vervolg: "Daar moet geen 
verdeeldheid (schismata) onder julle wees nie. Julle moet een wees in dieselfde gesindheid en met dieselfde oortuiging” (1 Kor 1:10; vgl 2 Kor 13:11). Alle Christene is één in Christus (Gal 3:28). Die Efesiërs word opgeroep om die eenheid wat die Gees tussen hulle gesmee het, te handhaaf deur in vrede met mekaar te leef, want daar is net één liggaam, één Gees, één hoop, één Here, één geloof, één doop en één God en Vader van almal (Ef 4:4-6) - en één maaltyd, sou ons kon byvoeg. Ook van die Filippense word verwag om eensgesind te wees, een in liefde, een van hart en een in strewe (Fil 2:2). Die geheim van kerkeenheid is liefde, "dit is die band wat (julle) tot volmaakte eenheid saambind" (Kol 3:14). Ook Petrus roep die gelowiges op tot ' $n$ lewe van eensgesindheid (1 Pet 3:8).

Die Nuwe-Testamentiese verkondiging is duidelik: Christene moet in vrede, harmonie en eenheid met mekaar saamleef in die lokale ekklesia en per konsekwensie as lokale ekklesia met alle ander ekklesiai. Berkhof (sj:37) konkludeer tereg: "van de helderheid en radicaliteit van het Nieuwe Testament zijn wij ver afgeraakt” (vgl ook Küng 1967:295; Schlink 1985:680).

Andersyds leer die Nuwe Testament ook 'n verskeidenheid van praktyke, geloofsuitdrukkings en lewenservarings in die Vroeë Kerk (Vlijm 1981:60-90; vgl Dunn 1977).

Hierdie verskeidenheid kan verwag word wanneer mense met soveel verskillende godsdienstige en kulturele agtergronde - Jode en heidene - die Christelike geloof aanneem en ' $\mathrm{n}$ nuwe bestaanswyse in die kerk onder leiding van die Gees en in die lig van die Woord moet vind. Dit kan verwag word dat Joodse Christene meer klem op die Ou Testament sou lê as Christene met 'n heidense agtergrond wat geen kennis van die Ou Testament gedra het nie (Vlijm 1981:71), trouens dit was juis hiérdie aspek wat soveel spanning in die Vroeë Kerk veroorsaak het ten opsigte van sake soos die besnydenis, Sabbat, maaltye en geloftes (Vlijm 1981:64-70) ${ }^{4}$.

Die vraag wat tans ontstaan, is of daar geen tekens van onenigheid en verskeurdheid in die Nuwe Testament sigbaar is nie. Moes die ekklesiai dan nie op hulle hoede wees vir wanopvattinge, valse leer en dwaalleraars nie? Moes die ekklesiai dan nie die geeste

4 Ons gee hier nie verder aandag aan die breuk tussen die kerk en Israel nie, al beklemtoon ons die belangrikheid daarvan [vgl Küng 91967:125-173); Berkhof (1990:260-264) en (uitgebreid) Van de Beek (2002b)]. 
ondersoek om te sien of hulle van God afkomstig is nie (1 Joh 4:1)? Is daar nie " $n$ voortdurende gevaar dat iemand ' $n$ "ander Jesus" (2 Kor 11:4) en 'n "ander evangelie” (Gal 1:6) kan verkondig as wat Paulus verkondig het nie?

Inderdaad is die Nuwe Testament vol waarskuwings teen valse leer en lewe. Daar is altyd die gevaar dat wrede wolwe in die kudde van Christus sal indring en gelowiges met leuens sal probeer verlei (Hand 20:29-30); die gevaar van dwaalleer wanneer valse leraars met slinksheid en listigheid die gemeente op dwaalweë wil wegvoer (Ef 4:14); van misleidende teorieë en argumente (filosofieë) (Kol 2: 8); van misleidende geeste en dwaalleraars en skynheilige leuenaars (2 Tim 4:1-5); van vreemde leringe (Heb 13:9); van valse profete en vals leraars wat dwaalleer insmokkel (2 Pet 2:1-3); van valse profete (1 Joh 4:6) en goddelose mense (Jud 4) - om slegs na hierdie enkele waarskuwings te verwys. En wat hierdie situasie so gevaarlik maak, is dat hierdie dwaalgeeste die kerk van Christus dikwels heimlik en onopsigtelik binnesluip (Jud 4; Hand 20:29).

Dit is duidelik dat die jong ekklesiai met talle en uiteenlopende gevare gekonfronteer was wat gevarieer het van valse leer (bv Judaïsme (Gal), gnostisisme (Kol; 1 Joh), tot onchristelike praktyke (1 Kor 5 \& 6).) Soms was die afval en afdwaling só groot dat ' $n$ mens byna sou kon huiwer om nog langer van die ekklesiai van Gód te praat.

Onophoudelik is die ekklesiai teen misleiding, verblinding en valse leer gewaarsku (Kol 2:16-23; 2 Tess 2:3; Heb 13:9; 2 Joh 7-8). Ons weet ook dat Christus self teen die suurdeeg van die Fariseërs ('tradisionaliste') en die Sadduseërs ('liberaliste') gewaarsku het (Matt 16:6; kyk hfst 23).

Die konsep haeresis het meesal 'n negatiewe konnotasie in die Nuwe Testament, byvoorbeeld in Galasiërs 5:5 en Titus 3:10 (wat handel oor valse lewe) en 2 Petrus 2:1 (valse leer). Maar in 1 Korintiërs 11:18-19 gebruik Paulus die woord haeresis (groepering/partyskap), nadat hy skeuring/verdeeldheid (schismata) in die gemeente afgewys het, in positiewe sin om aan te toon watter gelowiges die toets deurstaan (dit moes naamlik duidelik blyk watter lidmate aanvaar ' $n$ arm broer of suster in liefde tydens die gebruik van die nagmaal). Maar daar is hier nie sprake van enige vorm van skeuring nie. 
Die vraag ontstaan nou wát 'n ekklesia moet doen in gevalle waar ' $n$ vals leer of onchristelike optrede sigbaar aan die lig tree? Een moontlikheid is om jouself van die sondige broer of suster te onttrek (1 Kor 5:11; 2 Tim 3:5; 2 Joh 10-11). Maar dit moet sekerlik verstaan word teen die agtergrond van vooraf-vermanings teenoor die broer of suster (Matt 18:15-17; Tit 3:10). Ekskommunikasie is ' $n$ laaste moontlikheid (Matt 18:17; 1 Kor 5:7), maar selfs dán bly dit altyd ' $n$ feilbare menslike oordeel en nie ' $n$ finale goddelike veroordeling nie (kyk HK 31:85; KO art 71-80).

Daar is nêrens in die Nuwe Testament ' $n$ aanbeveling dat individuele Christene, of ' $n$ groep Christene, hulle van die lokale ekklesia moet losmaak nie, selfs wanneer daar 'n gebrek aan liefde in so ' $\mathrm{n}$ ekklesia ontstaan, soos in Efese (Op 2:4), of wanneer slegs ' $\mathrm{n}$ "paar mense" oor is wat nie hulle klere besoedel het nie, soos in Sardis (Op 3:4). Daar is eweneens nie ' $n$ aanduiding dat ' $n$ groep ekklesiai hulle van ander ekklesiai moet onttrek om sodoende ' $n$ nuwe 'denominasie' in teenstelling tot ' $n$ ander 'denominasie' te vorm nie. Daar is geen indikasie in die Nuwe Testament dat ware gelowiges, of ' $n$ groep van ware gelowiges, hulle van die (vals) ekklesia moet afskei om 'n ander nuwe ekklesia te vorm nie; inteendeel, die ekklesia(i) is deur Christus bemagtig om diegene wat in leer of lewe afdwaal te dissiplineer, selfs tot op die punt van ekskommunikasie. In baie gevalle was dit valse profete self wat die ekklesia verlaat het (1 Joh 2:19).

Daar is geen opdrag tot onttrekking aan die ekklesia nie, wél tot die neem van dissiplinêre stappe teen dwaalgeeste.

Die ekklesia van God is draer en beskermer van die waarheid (1 Tim 3:15). Die Gees van waarheid sal die kerk in die hele waarheid lei (Joh 16:13) en Christus sal sy kerk begelei tot by die voleinding van die wêreld (Matt 28:19).

Indien daar 'n probleem in 'n ekklesia ontstaan, byvoorbeeld hoe om die Ou Testament te interpreteer (oor die besnydenis), dan word ' $n$ duidelike lyn van optrede sigbaar: vergader saam, delibereer saam en besluit saam onder leiding van die Heilige Gees (Hand 15) (De Villiers 1986:23-47), sodat saam met al die gelowiges begryp kan word "hoe wyd en ver en hoog en diep die liefde van Christus strek" (Ef 3:18), om sodoende in liéfde by die wáárheid te bly (Ef 4:15). 


\section{MAG CHRISTUS VERDEEL WORD?}

In die lig van bostaande argumentering kan die legitieme vraag nou gestel word: kan daar in die kerk van Christus ooit 'n situasie ontstaan waar ' $\mathrm{n}$ kerkskeuring nie net onvermydelik is nie, maar ook noodsaaklik en selfs legitiem?

Dit is insiggewend dat selfs teoloë wat ' $n$ hoë premie op die eenheid van die kerk plaas, argumenteer dat 'n kerkskeuring soms onvermydelik kan wees. So oordeel Bavinck (1930:360) dat wanneer ' $n$ kerk meer gesag aan haar ampte en bedieninge en ordinansies heg as aan die Woord van God, en haar duidelik as ' $n$ valse kerk openbaar, dan het gelowiges die heilige plig om hulle af te skei en weer kerklik te gaan lewe volgens die Woord van die Here - hoewel Bavinck (1968:35) nie kerkskeuring tot die vlak van 'n geloofsartikel wil verhef nie. Min of meer dieselfde argumentasielyn word deur Berkhof (1990:397), Pannenberg (1993:411, 414), Schlink (1985:680, 700) en Wentsel (1998:273) gevolg.

Twee vrae dring hulle hiermee vanself na vore. Allereers, watter redes word gewoonlik vir 'n kerkskeuring aangevoer, en tweedens, op watter gronde kan so 'n optrede geregverdig word?

Die volgende vier redes word gewoonlik hier aangevoer:

Die eerste is: in geval van ekskommunikasie. Die rede is duidelik: is daar enige ander opsie vir ' $n$ gelowige wat Jesus Christus steeds as Verlosser en Here bely, maar wat, om watter rede ook al, deur die kerk geëkskommunikeer is, om 'n nuwe 'denominasie' te begin met ander gelowiges met wie dieselfde gebeur het?

In hierdie geval is daar egter verskillende kontekste. Terwyl Luther in lewensgevaar verkeer het toe die Rooms Katolieke Kerk hom in 1521 geëkskommunikeer het, was dit nie die geval met die Nederlandse teoloog Schilder, wat (ten onregte) deur die Gereformeerde Kerken in Nederland (GKN) in 1944 as teologiese professor afgesit is nie (vgl Berkouwer 1989:312-366). Wat sou gebeur het indien Schilder as lidmaat in die GKN aangebly het en teen sy afsetting beswaar gemaak het (vgl Veenhof 2005:144)? Dit is die ironie van die geskiedenis dat die 'denominasie' wat Schilder (en ander) in 1944 begin het, daarna in 1967 weer ' $n$ skeuring ervaar het en in 2003 'n kleiner afsplitsing. Gaan daar dalk 'n skismatiese tendens verskuil in Schilder se ekklesiologie (vgl breedvoerig Buys 2003)? 
' $\mathrm{n}$ Tweede rede is: waar daar sprake is van ' $n$ valse kerk. Die Nederlandse Geloofsbelydenis (1561) bely dat "niemand die reg het om hom af te skei nie" (van die ware kerk van Jesus Christus) en dat "almal wat hulle van hierdie ware kerk afskei of nie daarby aansluit nie, in stryd met die bevel van God handel” (art 29,28).

En tog verwys artikel 28 ook daarna dat alle gelowiges volgens die Woord van God "die plig het om hulle af te skei van hulle wat nie aan die [ware] kerk behoort nie.” Wat die vraag laat ontstaan: bestaan daar ook 'n plig tot afskeiding?

Die probleem wat hier na vore tree, is dat daar geen valse kerk in die absolute sin van die word bestaan nie (vgl Bremmer 1961:282, 363 (t o v Bavinck); Heyns 1992:347; Wethmar 1993:41-42; Wentsel 1998:272). In 'n verklaring van artikels 28 en 29 van die NGB moet die historiese en teologiese konteks van die sestiende eeu deeglik verreken word waar die Reformatore na die Rooms Katolieke Kerk (en veral die pousdom) as valse kerk verwys het, maar Protestantse kerke as ware kerke aanvaar het - hoewel Calvyn aanvaar het dat daar selfs onder die pousdom nog "kerke" kon wees (Institusie 4.2.12; vgl breedvoerig Nijenhuis 1959). Artikel 29 kan dus nie só vertolk word asof slegs die Gereformeerde kerke ware kerke was/is nie en dat die Anglikaanse en Lutherse kerke vals of sektaries sou wees (Polman sj:362). Calvyn het laasgenoemdes as ware kerke erken (Polman sj:234).

Daarom is dit uiters moeilik om kategories te sê: hiér is die valse kerk! [Daar is gereformeerde teoloë wat vandag nie meer die Katolieke Kerk as valse kerk beskou nie (Verhoef 2005:13), hoewel tog as “minder ware” kerk (Heyns 1992:348-349)].

Die situasie is selfs nog meer kompleks omdat geargumenteer word dat die merktekens van die ware kerk nie "permanente besittings" is nie, "they can be lost and regained" (Spykman 1992:462). Elke ware kerk moet voortdurend veg teen die valse kerk in eie boesem (Polman sj:378, 380). "De ware kerk kan ontrouw worden en via een proces van verwording in een valse kerk veranderen. Een kerk die als valse kerk beschouwd moet worden, kan door Gods genade nog tot bekering en hervorming komen” (Van Genderen \& Velema 1992:661).

Elke Christen, of groep Christene, of groep gemeentes wat getrou wil wees aan die intensies van artikels 28 en 29 van die NGB maar van die 'moederkerk' afskei, moet met oortuiging en 
vrymoedigheid kan sê dat die 'moederkerk' 'n valse kerk is. Waar hierdie oortuiging ontbreek, word in stryd met die konfessie gehandel.

Die vraag ontstaan nou wat die konsekwensie van hierdie gesigspunte is. Indien dit geldig is, beteken dit minstens dat alle Protestantse kerkgemeenskappe in sonde leef omdat hulle, hoewel in Christus verenig, tog afsonderlik van mekaar bestaan.

Ten einde aan die klem van hierdie gesigspunte te ontsnap, is 'n nuwe vindingryke oplossing ontwikkel: tussen die ware kerke (in die sin van 'denominasies') moet onderskei word tussen 'meer ware' en 'minder ware' kerke. Dit is beter, en verdien meer aanbeveling, om aan die 'meer ware' as aan die 'minder ware' kerk te behoort (Bavinck 1930:357; 1978:526; vgl ook Heyns 1978:376; Honig 1938:726-731).

Tog moet gesê word dat hierdie laaste onderskeiding nie net in stryd is met die Nederlandse Geloofsbelydenis nie (Polman sj:231), maar ook met die duidelike getuienis van die Nuwe Testament. Dit is ligjare verwyder van die Bybelse ekklesiologie waar die eenheid van die ekklesia(i) 'n onweerlegbare indikatief en imperatief is.

Hierby kan gevoeg word dat die logika van hierdie laaste onderskeiding verdag is: waarom sou hierdie onderskeiding nie ad infinitum volgehou kon word nie en by die 'meer ware' kerk weer verder onderskei word tussen 'meer meer waar' en 'minder meer waar' ensovoorts? Hierdie soort rasionalisasie kan baie maklik ' $n$ nimmereindigende proses van kerkskeuring legitimeer. Maar dit word dan ' $\mathrm{n}$ argumentum ad absurdum. Die onderskeiding 'meer/ minder waar' kan beskryf word as ' $\mathrm{n}$ rasionalistiese ontsnapping om die onenigheid van die kerk te regverdig, in klaarblyklike teenstelling met die Nuwe-Testamentiese ekklesiologie.

' $n$ Derde rede is: die oorsaak van kerkskeuring lê altyd by die ander (die meerderheid). Dis nooit die skeurmakers wat die kerk skeur nie, maar altyd die ander, die 'moederkerk', wat van die waarheid afgedwaal het en so die breuk veroorsaak (Momberg 2007:8, 10). Hierdie benadering hanteer kerkskeuring egter op 'n uiters simplistiese wyse en stel skeurmakers eintlik outomaties in die gelyk; dit maak ook van kerkskeuring ' $n$ byna vanselfsprekende en heel natuurlike aangeleentheid; en dit maak nie voldoende erns met die nagmaalsformulier wat waarsku teen skeurmakers in die kerk nie. Die Nuwe Testament ken nie hierdie sort argumentasie nie, dis reine rasionalisasie. Natuurlik is dit waar dat 
die minderheid dikwels gelyk gegee moet word, naamlik as hulle vashou aan die beloftewoord van God (Num 13), maar dis nié waar dat minderhede in die kerk altyd en outomaties reg en die meerderheid altyd verkeerd is nie en dat kerkskeuring (as 'n repeterende noodwendigheid) byna as ideaalbeeld voorgehou moet word.

' $n$ Vierde rede wat aangevoer word, is: in geval van ' $n$ laaste uitweg. Wat van 'n skeuring as laaste uitweg, as ultima ratio, wanneer alle pogings gefaal het om die bestaande kerk ('denominasie'), konsilies en sinodes van valse leer en lewe te oortuig?

Hier raak ons aan ' $\mathrm{n}$ besonder moeilike aangeleentheid, aangesien dit die defectibilitas en fallibilitas van die kerk van Christus raak. Het Christus dan nie belowe dat Hy altyd by sy kerk sal wees (Matt 28:20) en dat die Heilige Gees die kerk in die hele waarheid sal lei nie (Joh 16:13) - soos wat ons reeds eerder vermeld het?

Maar ons het ook gesien dat die ekklesia waaksaam moet wees vir valse profete en valse leer. Soos Noordmans (1986:370) opgemerk het: "Zonder liefde is er geen katholieke kerk. Zonder waarheid is er helemaal geen kerk. Ketterij is de grootste zonde in de christelijke gemeente. Zij maakt het Evangelie krachteloos” (vgl Küng 1967:278-300; Pannenberg 1993:412).

Bavinck (1930:299) bied in hierdie verband 'n weergawe van die klassieke gereformeerde (en Protestantse) visie: slegs wanneer die summa necessariae doctrinae en die praecipua religionis doctrina vir die leuen ingeruil word, is skeiding plig (m v n Calvyn). Dwaalleer, of dit nou ook al in Judaïstiese, gnostiese of ideologiese kleed verskyn, tref altyd die hart van die evangelie en verslaaf mense (Runia 1988:109). Daar is altyd die gevaar dat ' $n$ kerk kan konformeer aan ortodoksie maar kapituleer voor 'n ideologie (Berkouwer 1972:212-213). In Suid-Afrika is die teologiese regverdiging van apartheid (tereg) as ' $n$ dwaling verklaar (vgl Runia 1988:97-111) - en ek sien geen rede waarom nie dieselfde gedoen sou kon word met die teologiese regverdiging van 'n revolusie nie.

Slegs wanneer daar duidelike tekens is dat die essensie van die evangelie, dit wil sê die fundamentele artikels van die Christelike geloof ondermyn en ontken word, verskyn die moontlikheid van skeiding/skeuring op die horison. En slegs wanneer alle pogings van beswaar en protes gefaal het (Bremmer 1961:283). 
Die dringende vraag ontstaan nou of daar in die Nuwe Testament enige aanwysers is dat ' $n$ dwaling sulke afmetings kan aanneem dat dit nie net die bestaan en kontinuïteit van die kerk van Christus ondergrawe nie maar inderdaad met ondergang bedreig?

Dit sal van die opperste naïwiteit getuig om die gevaar van dwaling in die kerk van Christus te onderskat. Aan die ander kant sal dit van totale ongeloof en wantroue getuig om die feit te ontken dat Jesus Christus, in die krag van die Heilige Gees, die bose magte onttroon, ontwapen en ontmagtig het (Kol 2:15).

Dit bring ons by die tweede vraagstelling, naamlik die regverdiging van kerklike onenigheid/verdeeldheid.

Noudat 'denominasies' gekonfronteer word met die werklikheid van kerkverdeeldheid, in teenstelling met wat die Nuwe Testament leer, is daar net een uitweg en dit is om die verdeeldheid deur middel van rasionalisering te legitimeer. "Net een uitweg" het ek geskryf, maar dit is nie heeltemal korrek nie, want die twintigste eeu is al beskryf as die "eeu van ekumene", aangesien talle ekumeniese bewegings in hierdie eeu ontstaan het, soos die Gereformeerde Ekumeniese Sinode (tans Raad)(GER) (1946) en die Wêreldraad van Kerke (1948). Die Wêreldbond van Gereformeerde Kerke (WBGK) het reeds in 1875 ontstaan en die GER is tans in ' $n$ proses van vereniging met die WBGK.

Vir lang tye - en in sommige gevalle tans nog - was rasionalisasie en legitimasie van die verskeurde situasie egter aan die orde van die dag. Maar waaruit bestaan die belangrikste rasionalisasies?(vgl Berkhof sj:42-50; Küng 1967:323-326; Veenhof 1969:119-126; Van Wyk 1990:11-14; McGrath 1995:419-420; Wentsel 1998:250 ev; 2006:163-177).

(1) Daar is verdeeldheid as gevolg van God se ewige raad. Hierdie argument kan egter nouliks ernstig opgeneem word. Dit kan immers maklik aanleiding gee tot die idee dat God die oorsaak van sonde is. Tereg het Berkhof (sj:39) hieroor opgemerk: "Dit raadsplan is een rustpunt voor het worstelend geloof, geen oorkussen voor ongehoorzaamheid".

(2) Daar is verdeeldheid vanweë God se voorsienigheid. Alhoewel Bavinck (1930:300-301) die verdeeldheid tussen kerke skerp kritiseer, verswak hy onmiddelik sy argument met ' $n$ verwysing na die voorsienigheid van God (Bavinck 1930:301). Maar dit is 
onaanvaarbaar, want die voorsienigheid van God mag nie deur ons gebruik word as verskoning vir ons sonde nie, maar is bedoel as ' $n$ troos in troebel tye en as ' $n$ inspirasie tot verantwoordelike optrede. Alles wat in die wêreld (en kerk) gebeur, word wel deur God beheer, maar mag nie simplisties met sy geopenbaarde wil geïdentifiseer word nie. God wil dat sy ekklesia(i) in eenheid en vrede sal saamleef.

(3) Daar is verdeeldheid as gevolg van die sonde. Dit word wyd aanvaar dat die oorsaak van kerkverdeeldheid toegeskryf kan word aan sonde en die gevolge van sonde (Barth 1960:756; Acta GKSA 1964:197). Natuurlik is dit waar dat met elke kerkskeuring sonde (by alle betrokke partye) 'n groot rol speel. Sonde (en die uiteengeslane kerk - liggaam! - van Christus) is egter nie 'n realiteit wat gelate aanvaar moet word nie, maar ' $n$ werklikheid wat weerstaan en bestry behoort te word, juis vanweë die feit dat Christus reeds deur sy kruis en opstanding oor die sonde getriomfeer het.

(4) Daar is verdeeldheid omdat God verskeidenheid gewil het. Dit is natuurlik waar dat God se skepping deur verskeidenheid en pluraliteit gekenmerk word; en dit is waar dat daar in ' $n$ lokale ekklesia asook tussen onderskeie ekklesiai verskeidenheid, variasie, pluraliteit en pluriformiteit bestaan, maar dit is nié waar dat God daarmee verdeeldheid, onenigheid en skeuring tussen die onderskeie ekklesiai gewil het nie. Verskeurdheid kan nie vanuit die Nuwe Testament gesubstansieer word nie (Berkouwer 1970:61-93 teenoor Kuyper; Wentsel 1998:278-288). Om vanuit die konsep van 'verskeidenheid' in die Nuwe Testament te konkludeer tot die sogenaamde waarheid van 'verskeurdheid' veronderstel ' $n$ identifisering van die betekenis van twee verskillende begrippe, wat logies ontoelaatbaar is.

Hierdie konsep-identifikasie blyk ook duidelik uit die argumentasie van Nürnberger (1975:414), wat aan die een kant toegee dat die verdeeldheid "die direkte gevolg van die sonde is", maar aan die ander kant aanvoer dat daar "absoluut niks met hierdie verskeidenheid (sic)” van kerke (Baptiste, Anglikane ens) verkeerd is nie (Nürnberger 1975:429). Bavinck (1968:39) kan selfs opmerk dat die onenigheid van die kerk nie net sleg is nie, maar dat dit ook bepaalde voordele inhou: "De rijkdom, de alzijdigheid, de veelvormigheid van het Christelijk geloof wordt er in openbaar". 
Hierdie konsepverwarring blyk ook duidelik uit die kritiese weergawe van die Nuwe-Testamentiese ekklesiologie deur Käsemann (1964:95-107; 1969:252-259), waar hy ongenuanseerd vanuit die verskeidenheid in die ekklesia(i) konkludeer tot die verskeurdheid tussen die ekklesiai - soos ons dit vandag ervaar. Van Aarde (1987:325-351; 1989:461-475) sluit in hierdie verband by Käsemann aan en identifiseer ten onregte die begrippe 'verskeidenheid' en 'verskeurdheid'. Daarby voer hy in sy argumentasie 'n nuwe konsep denominasie in (wat verwys na ekklesiai in opposisie teenoor ander ekklesiai), wat nêrens, nie eers implisiet nie, in die Nuwe Testament - en dit gaan tog oor NuweTestamentiese gegewens - ter sprake kom (Van Aarde 1989:467).

Dieselfde kritiek kan ingebring word teen die sogenaamde 'vertakkingsteorie', naamlik dat die 'een kerk' met die verloop van tyd soos die takke van een boom vertak het in 'talle kerke'. Hierdie poging probeer die irrasionele rasionaliseer.

(5) Daar is verdeeldheid omdat die ware eenheid onsigbaar en geestelik van aard is. 'n Baie populêre rasionalisasie is dat ons vir die eenheid van die kerk nie moet soek in sigbare en uiterlike gestaltes nie, maar in die onsigbare, innerlike en geestlike eenheid in die geloof (Honig 1938:728; vgl ook Bavinck 1930:304-305; Spoelstra 1986:4-17). Vanselfsprekend moet daar toegegee word dat gelowiges deur ' $n$ onsigbare band geestelik met Christus verenig is deur die Heilige Gees (Wethmar 1999:78), maar hierdie band met Christus openbaar homself in liturgiese vorme en Christelike aktiwiteite. Die kerk moet die lig vir die wêreld - en daarom sígbaar - wees ten einde mense nader na God te bring (Matt 5:14-16). Die eenheid van die gelowiges met Christus, en onderling met mekaar, moet in die wêreld gesién kan word sodat mense in die wêreld tot geloof kan kom dat die Vader Hom gestuur het (Joh 17:21, vgl Wentsel 2006:162).

Daarby handel diegene wat slegs aan ' $n$ 'onsigbare' eenheid glo, inkonsekwent solank die eie 'denominasie' voortgaan met kerkvergaderings en sinodes. Waarom dan nie ook 'eie' sinodes afskaf en kies vir ' $n$ volledige independentistiese vorm van kerkverband en kerkregering nie?

(6) Daar is verdeeldheid, geen probleem nie, want 'my' kerk is die enigste ware kerk. Met hierdie standpunt word 'my denominasie' verabsoluteer tot die enigste ware kerk, maar so 'n standpunt - het 
ons alreeds vasgestel - is onhoudbaar (Berkhof sj:43-46). In die Nuwe Testament word daar nêrens na 'my' kerk verwys nie, want die kerk is altyd die kerk van Jesus Christus, waaraan ek mag behoort, wat ek moet dien en wat as instrument van die komende koninkryk van God funksioneer.

(7) Daar is verdeeldheid, moenie bekommerd wees nie, in die eskatologiese toekoms sal alle Christene een wees in Christus. Hierdie opsie kan beskryf word as eskatologiese 'escapisme'. Natuurlik is dit waar dat alle Christene in die eschaton verenig sal wees in Christus, maar dit is nie waarvoor Christus gebid het nie. Hy het gebid vir eenheid hier en nou, midde in ' $\mathrm{n}$ wêreld van onenigheid, verdeeldheid, wantroue, onversoenlikheid, vyandskap en haat, sodat die wêreld kan glo dat die Vader Hom gestuur het, Hy wat die sonde van die wêreld wegneem en wat eenheid en vrede in die wêreld bring.

Daar kan slegs een konklusie wees ten opsigte van al hierdie rasionalisasies: "All attempts to justify disunity is contraband" (Spykman 1992:443). Elke Christen moet die eenheid van die kerk nastreef en behoort alle rasionalisasies te verwerp wat die onenigheid probeer legitimeer (Roberts 1986:85). Waarvoor Christus gebid het, en wat die Nuwe Testament leer, is die eenheid van die kerk, wat verskeidenheid inderdaad insluit, maar nooit verskeurdheid of onenigheid nie. Dit kan beskryf word as ' $n$ eenheid-inverskeidenheid - wat iets anders is as ' $n$ kleurlose eendersheid en eenvormigheid. Dit is ' $n$ eenheid-in-geloof, 'n eenheid-in-hoop, ' $n$ eenheid-in-liefde, eenheid-in-waarheid, eenheid-in-sending, eenheidin-liturgie, eenheid-in-erediens, eenheid-in-kerkregering en ' $n$ eenheid-in-Christelike-lewe ${ }^{5}$.

\section{KONKLUSIE}

Ons het 'n lang pad afgelê met die strydende kerk van Christus, aangeveg deur verdeeldheid, verskeurdheid, onenigheid, afskeiding,

5 Die oorspronklike voordrag (by IRTI) bevat hier ' $n$ gedeelte wat handel oor die roete op weg na kerkeenheid, waar die volgende aspekte behandel is: (1) skuldbelydenis, (2) interlike kerklike gesprek, (3) interkerklike samewerking, (4) interkerklike/ekumeniese vergaderings, (5) lesse oor geslaagde kerkverenings, (6) eenheid/eenwording ter wille van die koms van die koninkryk van God, (7) die waarde van 'n nuwe geloofsbelydenis, (8) toekeer na Christus as sentrum en (9) die waarde van gebed. Ruimte ontbreek egter om in hierdie artikel daaraan aandag te gee. 
verwydering, fragmentasie en skisma. Dit is ' $\mathrm{n}$ roete van skade en skande waarvan Bavinck (1930:300-301) die volgende gesê het:

Ook is het niet te ontkennen, dat de eindelooze gedeeldheid van de belijders van Christus aan de wereld eene oorzaak biedt van vreugde en spot, en haar een reden geeft voor haar ongeloof aan den Gezondene des Vaders, wijl zij de eenheid der geloovigen in Christus niet ziet, Joh 17:21. Wij kunnen ons als Christenen niet diep genoeg verootmoedigen over de scheuring en tweedracht, die alle eeuwen door in de kerk van Christus heeft bestaan; zij is eene zonde tegen God, in strijd met de bede van Christus, en veroorzaakt door de duisternis van ons verstand en de liefdeloosheid van ons hart" (m v n Gunning).

Barth (1960:754) stel dit weer só:

Es gibt aber keine theologische, keine geistliche, es gibt auch keine biblische Rechtfertigung der Existenz einer Vielheit solcher real getrennter, sich innerlich und darum auch äusserlich gegenseitig ausschliessender Kirchen. Viele Kirchen in diesem Sinn bedeutet: viele Herren, viele Geister, viele Götter. Keine Frage: in dem Mass, als die Christenheit in wirklich verschiedenen und entgegengesetzten Kirchen existiert, in dem Mass leugnet sie praktisch, was sie theoretisch bekennt: die Einheit und die Einzigkeit Gottes, Jesu Christi, des Heiligen Geistes

(so ook Schlink 1985:683).

In die Vroeë Kerk was kerkskeuring teologies onaanvaarbaar (Cyprianus, Augustinus), later is dit wel onder bepaalde uitsonderlike voorwaardes gebillik (Luther, Calvyn), nog later is dit as onvermydelike gebeure goedgekeur (Na-Reformasie) en vandag word ' $n$ skisma haas probleemloos verwelkom en byna tot ' $n$ noodsaaklike teologiese prinsipe verhef. Laasgenoemde standpunt verteenwoordig egter ' $n$ sektariese en sekulêre ekklesiologie, totaal vreemd aan en in direkte stryd met die Nuwe-Testamentiese ekklesiologie.

Veral in Suid-Afrika, met sy tragiese geskiedenis van apartheid, onenigheid en afsonderlikheid, ook op kerklike gebied, ontvang die saak van die eenheid van die kerk ' $n$ besondere aksent. 
Die kerk is immers God se eksemplariese versoeningsgemeenskap wat vrede en versoening in ' $n$ verdeelde samelewing moet voorleef en demonstreer. Misluk die kerk hierin, dan faal sy grootliks in haar roeping in hierdie wêreld (vgl Pityana \& Villa-Vicencio 1995).

In hierdie verband het die gereformeerde teologie, algemeen gesproke, hom ver verwyder van sy slagspreuk sola Scriptura. Nêrens anders in die gereformeerde teologie word die invloed van die Aufklärung, met sy beklemtoning van rasionalisme en individualisme, sigbaarder as in die ekklesiologie nie. Dit is egter nodig dat die beginsel van sola Scriptura hier gekomplementeer word met dié van die solo Christo asook die solo Spiritu, want sonder die verligtende werk van die Heilige Gees bly die Woord (die Ou Testament) versluier (2 Kor 3:12-18, kyk Greijdanus 1946:4041). Dit is die Gees wat die mens se hart ontsluit om Christus as die sentrum van die Godsopenbaring (Heb 1:1-2) te ontdek en wat mense volgens sy beeld transformeer.

Die pad na eenheid is ' $\mathrm{n}$ moeilike en gevaarlike pad. Want hoe kan die gevare van sinkretisme en relativisme, van sektarisme en absolutisme, van pragmatisme en pluralisme (as ismes) op die weg na sigbare eenheid vermy word?

Maar hoe groot die gevare ook al mag wees, 'op weg' na die toekoms beskik die kerk oor onverwoesbare beloftes. Eerstens het ons die belofte van die Vader dat Hy die goeie werk wat Hy in sy kerk begin het, end-uit sal voer en dit sal voleindig op die dag wanneer Christus Jesus kom (Fil 1:6).

Tweedens het ons die belofte van Christus, wat oor sonde en dood en demone getriomfeer het, dat $\mathrm{Hy}$ al die dae tot die voleinding by sy kerk sal wees (Matt 28:20) (vgl Berkouwer 1970:110; Van de Beek 2002a:129).

Derdens het ons die belofte dat die Heilige Gees die kerk in die hele waarheid sal lei (Joh 16:13). Uiteindelik "vermag ons niks teen die waarheid van God nie, maar wel alles vir die waarheid" (2 Kor 13:8). Uiteindelik sal die waarheid seëvier. Veritas vincet!

Die realisering van die eenheid van die kerk van Christus is in die laaste instansie ' $n$ vraag na ons vertroue in God. Vertrou ons God wérklik dat Hy eendag tot voltooiing sal bring wat Hy beloof het en dat die gebed van Christus in vervulling sal gaan - en dat die wêreld sal glo? 


\section{Literatuurverwysings}

Acta GKSA 1964. Handelinge van die vyf-en-dertigste Sinodale Vergadering van die Gereformeerde Kerk in Suid-Afrika. Potchefstroom.

Barth, K 1960. Die Kirchliche Dogmatik IV/1. Zürich: EVZ-Verlag.

Bavinck, H 1930. Gereformeerde Dogmatiek 4. Kampen: Kok.

-, 1968. De Katholiciteit van Christendom en Kerk. Kampen: Kok (oorspr 1888).

-, 1978. Our reasonable faith. A survey of Christian doctrine (vert H Zylstra). Grand Rapids: Baker.

Berkhof, H sj. God's éne kerk en onze vele kerken. Nijkerk: Callenbach.

-, 1990. Christelijk Geloof. Een inleiding tot de geloofsleer. Nijkerk: Callenbach.

Berkouwer, G C 1970. De Kerk I. Eenheid en katholiciteit. Kampen: Kok.

-, 1972. De kerk II. Apostoliciteit en heiligheid. Kampen: Kok.

1989. Zoeken en vinden. Herinneringen en ervaringen. Kampen: Kok.

Bremmer R H 1961. Herman Bavinck als dogmatikus. Kampen: Kok.

Buys, A L A 2003. Die moeder van ons almal. Die ekklesiologie van Klaas Schilder. DTh-proefskrif, UV, Bloemfontein (ongepubliseer).

Calvyn, Institusie van die Christelike Godsdiens 1559 (vert H W Simpson). Potchefstroom: CJBF.

De Villiers, P 1986. Die apostelkonvent (Handelinge 15), in Breytenbach, C (red), Eenheid en konflik. Eerste beslissinge in die geskiedenis van die Christendom, 23-47, Pretoria: NG Kerkboekhandel.

Dunn, J G D 1977. University and diversity in the New Testament. An inquiry into the character of earliest Christianity. London: SCM Press.

Durand, J 1986. Jesus se gebed om eenheid en solidariteit te midde van krisis en konflik, in: Breytenbach, C (red), Eenheid en konflik. Eerste beslissinge in die geskiedenis van die Christendom, 105-133. Pretoria: NG Kerkboekhandel.

Greijdanus, S 1946. Schriftbeginselen ter Schriftverklaring en historisch overzicht over theorieën en wijzen van Schriftuitlegging. Kampen: Kok.

Heyns, J A 1978. Dogmatiek. Pretoria: NG Kerkboekhandel.

-, 1992. Inleiding tot die dogmatiek - aan die hand van die Nederlandse Geloofsbelydenis. Pretoria: NG Kerkboekhandel.

Honig, A G 1938. Handboek van de Gereformeerde Dogmatiek. Kampen: Kok.

Käsemann, E 1964. Essays on New Testament Themes. (transl. W J Montagne) London: SCM Press.

-, 1969. New Testament questions of today (transl. W J Montagne). London: SCM Press.

Küng, H 1967. De Kerk. Hilversum: Paul Brand. 
McGrath, A E 1995. Christian Theology. An Introduction. Oxford: Blackwell.

Momberg, H L J 2007. Kerkeenheid en kerkverband. Waarheid en Dwaling 13(12), 6-10.

Nijenhuis, W 1959. Calvinus Oecumenicus: Calvijn over de eenheid der kerk in het licht van zijn briefwisseling. s'Gravenhage: Martinus Nijhoff.

Noordmans, O 1986. Verzamelde Werken. Deel VI. De kerk en het leven. Kampen: Kok.

Nürnberger, K 1975. Sistematiese Teologie. Genadendal: Teologiese Seminarie van die Evangeliese Broederkerk in Suid-Afrika.

Pannenberg, W 1993. Systematic Theology Vol 3 (transl. W Bromiley). Grand Rapids: Eerdmans.

Pityana, B N \& Villa-Vicencio, C (eds.) 1995. Being the church in South Africa today. Johannesburg: SACC.

Polman, A D R sj. Onze Nederlandsche Geloofsbelijdenis. Verklaard uit het verleden, geconfronteerd met het heden. Deel 3. Franeker: Wever.

Roberts, J 1986. Die eenheid van die kerk volgens die Efese-brief, in: Breytenbach, C (red), Eenheid en konflik. Eerste beslissinge in die geskiedenis van die Christendom, 75-88. Pretoria: N G Kerkboekhandel.

Runia, K 1988. Wat is ketterij? in Wethmar, C J \& Vos, C J A (reds), ' $n$ Woord op sy tyd. ' $n$ Teologiese feesbundel aangebied aan professor Johan Heyns ter herdenking van sy sestigste verjaardag. Pretoria: NG Kerkboekhandel, 97111.

Schlink, E 1985. Ökumenische Dogmatik. Grundzüge. Göttingen: Vandenhoeck \& Ruprecht.

Schmidt, K L 1985. Ekklesía in Kittel G \& Friedrich G (eds.), Theological Dictionary of the New Testament (transl. G W Bromiley). Grand Rapids: Eerdmans, 394-402.

Schuman, N A. 1981. Pluraliteit in het Oude Testament. Vreedzame coëxistentie en conflict, in: Vlijm J M (ed.), Geloofsmanieren. Studies over pluraliteit in de kerk. Kampen: Kok, 16-59.

Snyman, W J 1977. Nuwe en ou dinge. Uit die skat van die koninkryk. Potchefstroom: Pro Rege.

Spoelstra, B 1986. Het ons kerk-wees in strukture gestol? In die Skriflig, 4-17.

Spykman, G J 1992. Reformational Theology. A new paradigm for doing Dogmatics. Grand Rapids: Eerdmans.

Van Aarde, A G 1987. Gedagtes oor die begin van die kerk - 'n geskiedenis van versoenende verskeidenheid. Hervormde Teologiese Studies 43(3), 325-351.

-, 1989. 'n Nuwe-Testamentiese begronding van die eenheid van die kerk en die eis om kerkeenheid vandag. Hervormde Teologiese Studies 45(2), 461475. 
Van de Beek, A 2002a. The disunity of the Reformed Church, in Visscher, L et al, The church in Reformed perspective. A European reflection. Genéve: Centre of International Réformé John Knox, 109-133.

-, 2002b. De kring om de Messias. Israel als volk van de lijdende Heer. Zoetermeer: Meinema.

Van Genderen, J \& Velema, W H 1992. Beknopte Gereformeerde Dogmatiek. Kampen: Kok.

Van Wyk, J H 1990. Geroep tot eenheid, in Kruger, P \& Du Toit, H, (reds.). Geroep tot eenheid. Gesprekke ter wille van die heling van die breuk tussen die GKSA en NGK, 6-30. Pretoria: NG Kerkboekhandel.

Veenhof, C 1969. Volk van God: Enkele aspecten van Bavincks kerkbeschouwing. Amsterdam: Buijten \& Schipperheijn.

Veenhof, J. 2005. Vrij gereformeerd (Verzamelde artikelen bezorgd door D van Keulen et al). Kampen: Kok.

Verhoef, P A 2005. Op vaste fondamente. Kerk en dwaalleer - les van die geskiedenis. Stellenbosch: Stellenoord.

Vlijm, J M (ed) 1981. Geloofsmanieren. Studies over pluraliteit in de kerk. Kampen: Kok.

Wentsel, B 1998. Dogmatiek 4b. De Heilige Geest, de Kerk en de Laatste Dingen. Kampen: Kok.

-, 2006. Hij-is-er-bij. Handboek Bijbelse Geloofsleer I. Kampen: Kok.

Wethmar, C J 1993. Die ekumeniese roeping van die kerk in die lig van die Gereformeerde belydenisskrifte/Ekumenisiteit in dogma teologiese perspektief, in Crafford, D \& Gous, G (reds), Een liggaam -baie lede. Die kerk se ekumeniese roeping wêreldwyd en in Suid-Afrika, 37-55, Pretoria: ISN/Verba Vitae.

-, 1999. Ecclesiology and Theological Education, in Van Egmond, A \& Van Keulen, D (eds.), Church and Ministry (Studies in Reformed Theology 3), 71-89. Kampen: Kok. 